\title{
VEGETATIVE STAGE OF STRAWBERRY DURATION DETERMINED BY THE CROP YEAR ${ }^{1}$
}

\author{
ROSIANI CASTOLDI DA COSTA², EUNICE OLIVEIRA CALVETE ${ }^{3}$, \\ JOSÉ LUÍS TREVIZAN CHIOMENTO ${ }^{4}$, NICOLAS DOS SANTOS TRENTIN ${ }^{5}$, \\ FABIOLA STOCKMANS DE NARDI ${ }^{6}$
}

\begin{abstract}
Over the years, strawberry growth has shown alterations in its phenology, involving mainly the beginning of flowering and fruiting. The aim of this study was to verify whether the growth years influence the duration of strawberry vegetative and reproductive stages in protected environment. The development of the Camarosa strawberry cultivar was observed between 2007 and 2014. The crops were settled in a greenhouse in the Horticulture Sector at the University of Passo Fundo, RS. Data like transplant date, in the beginning and end of the fruits harvest; temperature data (maximum, average and minimum) were recorded in the growth environment. These data were used for the thermal sum calculation (daily, accumulated). The data analyses were carried out in a descriptive manner, relating the temperature data with the phenological stage of each year. The accumulated thermal sum that is necessary to begin the harvest was variable throughout the years, where it was between 383 and 438 degrees days $^{-1}$ for plants with interval between transplant and harvest of 73 days (2008 and 2009) at 816 degrees days $^{-1}$, where the interval was 111 days (in 2014). In the first case, it accumulated $5.2{ }^{\circ} \mathrm{C} /$ day, in 2008 and $6{ }^{\circ} \mathrm{C} /$ day, in 2009 . In the second case, it was $7.3{ }^{\circ} \mathrm{C} /$ day, in 2014. Seedlings which were transplanted in the first fortnight of May began fruiting in the beginning of August and September. Seedlings transplanted in July 2011 and 2012 began fruiting in similar periods, that is, in the first and second fortnight of September. It was found that, because of the temperatures recorded in different periods of growth and transplant time, there is alteration mainly in the strawberry vegetative stage. Index terms: Fragaria $\mathrm{x}$ ananassa Duch, phenology, accumulated thermal.
\end{abstract}

\section{DURAÇÃO DA FASE VEGETATIVA DO MORANGUEIRO É DETERMINADA PELO ANO DE CULTIVO}

RESUMO- Ao longo dos anos, o cultivo do morangueiro tem apresentado alterações em sua fenologia, envolvendo, principalmente, o início de floração e frutificação. O objetivo do trabalho foi verificar se os anos de cultivo interferem na duração das fases vegetativa e reprodutiva do morangueiro, em ambiente protegido. Foi observado entre os anos de 2007 a 2014, o desenvolvimento da cultivar de morangueiro Camarosa. O ambiente no qual se estabeleceram os cultivos foi uma estufa agrícola no Setor de Horticultura da Universidade de Passo Fundo, RS. Registraram-se dados como data de transplante, início e final de colheita dos frutos; dados de temperaturas (máximas, médias e mínimas) registradas no ambiente de cultivo. Esses dados foram utilizados para cálculo da soma térmica (diária, acumulada). A análise de dados foi realizada de forma descritiva, relacionando os dados de temperatura com os estádios fenológicos em cada ano. A soma térmica acumulada necessária para iniciar a colheita foi variável nos anos, ficando entre 383 e 438 graus dias ${ }^{-1}$ para plantas com intervalo entre transplante e colheita de 73 dias (anos de 2008 e 2009) a 816 graus dias ${ }^{-1}$, em intervalo de 111 dias (em 2014). No primeiro caso, acumulou-se $5,2^{\circ} \mathrm{C} / \mathrm{dia}$, em 2008 e 6 ${ }^{\circ} \mathrm{C} /$ dia, em 2009. No segundo, foi de $7,3^{\circ} \mathrm{C} / \mathrm{dia}$, em 2014. Mudas transplantadas na primeira quinzena de maio iniciaram a frutificação no início de agosto e setembro. Mudas transplantadas em julho de 2011 e 2012 iniciaram em período semelhante, primeira e segunda quinzena de setembro. Constatou-se que, em função das temperaturas registradas nos diferentes anos de cultivo e épocas de transplante, há alteração principalmente na fase vegetativa do morangueiro.

Termos para indexação: Fragaria x ananassa Duch., fenologia, soma térmica umulada.

\footnotetext{
'(Paper 107-16). Received August 16, 2016. Accepted May 10, 2017.

${ }^{2} \mathrm{PhD}$ in Agronomy, CAPES scholarship/PNPD the Graduate Program in Agronomy (PPGAgro) of Universidade de Passo Fundo (UPF). E-mail: rosianicastoldi@yahoo.com.br

${ }^{3}$ Agricultural Engineer. PhD in Plant Science, Agronomy Course Full Professor of the Faculdade de Agronomia e Medicina Veterinaria(FAMV) and PPGAgro Coordinator of UPF.E-mail: calveteu@upf.br

${ }^{4}$ Agricultural Engineer Master in Agronomy PPGAgro of the UPF.. E-mail: jose-trevizan@hotmail.com

${ }^{5}$ Undergraduate of Agronomy course of FAMV, UPF scholarship of scientific initiation - Fapergs. E-mail: ntrentin@gmail.com

${ }^{6}$ Agricultural Engineer, Ms. in Agronomy from PPGAgro the UPF. E-mail: fabiolastockmans@hotmail.com
} 


\section{INTRODUCTION}

Agriculture represents one of the main world economic sectors and it is directly related to weather conditions. Because of that, scientific researches are used as a basis for possible maintenance strategies of the food productive sector in the levels demanded by the consumer market.

An evaluation of possible environmental impacts on cultivation, caused by climate change, must take into consideration the interaction between biotic and abiotic factors (ZHANG et al., 2017). This is also true when it comes to strawberry growth.

Over the years, the strawberry growth has shown changes in its phenology (COSTA et al., 2016), involving, mainly the beginning of flowering and fruiting, thus these processes are directly related to the seedlings transplanting time.

The seedlings used by producers in the Brazilian subtropic are developed mainly in the Argentinian and Chilean Patagonia, what makes feasibility planting at the suggested time difficult (beginning of fall), limiting the transplant to the delivery of seedlings.

It was observed that, because of this irregularity, there are changes in the culture cycle. These changes can be related to the development of the seedling that needs some hours of cold to accumulate carbon in its crown and to change stage (TAZZO et al., 2015).

We emphasize that leaf assimilates, which must be storaged in the crown, are determinants to the production of strawberry fruits, thus they are closely related to the temperatures recorded during the period of seedlings development, yet in the nursery. This cold accumulation results in an increase of the plant crown diameter (COCCO et al., 2012), which is the main characteristic used to determine the seedlings quality, that must show a diameter superior to $8 \mathrm{~mm}$ (TORRES-QUEZADA et al., 2015). This way, the temperature conditions in which the seedlings are developed need to satisfy the needs of each cultivar (HIDAKA et al., 2017) so that soon after transplant, all energies are translocated only for floral induction and, later, for fruiting (TORRES-QUEZADA et al., 2015), because the quality of the strawberry seedlings at the time of planting is directly correlated with the precocity of production (COCCO et al., 2015).

However, nursery gardeners do not provide information related to cold accumulation in seedlings from Chile and Argentina to producers. Such information would be extremely important to encourage the thermal need of the plant in each stage, thus the thermal sum accumulated (TSa) in the seedling formation, associated to climate conditions of the transplanting site will make scheduling production feasible, making possible to indicate appropriately the best planting period. This way, the TSa is a tool that makes the understanding of the culture cycle possible after the seedlings reception.

The literature related to phenology of crops emphasizes the impact caused by temperature changes that influences phenostages of plants (leaf development, flowering, fruiting, senescence and abscission) (GE et al., 2015; WANG et al., 2015). The duration of the growth period and the schedule of phenological stages are directly related to these changes (FU et al., 2013), that present substantial interannual variability, mainly in the beginning and end of the growth period, what corresponds to the period that involves greater activity in the cycling of carbon, water and nutrients (LOVAISA et al., 2015).

Other factors like genotype (RAHMAN et al., 2016), initial weight of the plant (BARTCZAK et al., 2010), number of leaves (COSTA et al., 2014) and application of fertilizers (LOVAISA et al., 2015) can also influence the phenological development of the plant.

In this context, the aim of this study was to verify whether strawberry growth years, in protected environment, influence the duration of vegetative and reproductive stages of the plant.

\section{MATERIAL AND METHODS}

\section{Plants and growth site}

The development of strawberry cultivar Camarosa (short days) from Chile, has been observed throughout seven years (from 2007 to 2014). During the years of observation, the plants were led to the same local and to the same growth system (soil), in rural greenhouse, with semicircular roof and area of $510 \mathrm{~m}^{2}$, covered with low density polyethylene (LDP) of $150 \mu \mathrm{m}$ thickness, with additive antiultraviolet and anti-drip added. The plants were placed in covered beds with mulching plastic in a spacing of $0.30 \mathrm{~m} \times 0.30 \mathrm{~m}$, under a dripping irrigation system. Fertigation was used according to development stages of the crop (CALVETE et al., 2007). This study was developed in the Sector of Horticulture of the Agronomy and Veterinary College (FAMV) at the University of Passo Fundo (UPF) (2814'0.03’'S; 52²2'51.94”O).

\section{Procedures \\ Development of the plants}

In order to determine the growth cycle of cultivar Camarosa, data related to the transplanting 
date, beginning and end of the fruits harvest (Figure 1) were recorded each year.

\section{Thermal sum}

Maximum, average and minimum temperatures recorded by a termo-hygrograph during the growth years, installed at $1.5 \mathrm{~m}$ height inside the greenhouse were considered. These data were used for calculation of the thermal sum. The daily mean temperature $(\mathrm{dmT})$ was calculated by the following equation: $\mathrm{dmT}=(\mathrm{t} 0+\mathrm{t} 2+\ldots+\mathrm{t} 24) / 12$; which calculate the arithmetic mean of temperatures $\left({ }^{\circ} \mathrm{C}\right)$ recorded by the termo-hygrograph every one hour. The daily thermal sum (dTS) was calculated in accordance with what was proposed by Gilmore and Rogers (1958) and Arnold (1960), through equation $d T S=(d m T-b T)$ $\left[{ }^{\circ} \mathrm{C} \mathrm{day}^{-1}\right]$ where, $d m T=$ daily mean temperature and $b T=$ base temperature.

The base temperature (bT) is defined as the minimum temperature, and when the temperature is lower than that, there is no emission of leaves. The bT considered for strawberry was $7.2^{\circ} \mathrm{C}$. The dTS was accumulated from the seedlings transplant, resulting in thermal sum accumulated (TSa), that is: $\mathrm{T} S a=\Sigma d T S$.

\section{Data analysis}

The analysis was carried out in a descriptive manner, relating the temperature data with the phenological stage every year of growth.

\section{RESULTS AND DISCUSSION}

Based on observations of the data related to temperature, growing stages and development of strawberry, we found out that the growth years influenced mainly in the vegetative stage of the plants.

During the years studied, it was observed that the period between the transplanting date to the beginning of flowering (anthesis), approximately one month before harvest, the plants were submitted to the temperature which has been considered as great, that is, lower than $15^{\circ} \mathrm{C}$ (Figure 2) to this process (HIDAKA et al., 2017).

Short-day plants have floral evocation under temperatures of around $15{ }^{\circ} \mathrm{C}$, condition in which the gene constans that is responsible for activating flowering genes in long photoperiod, is inhibited, activating another gene, the $\mathrm{Hd} 3$, which is activated because of the low concentration of constans due to the photoperiod is not inductive. Hd3 corresponds to the florigene that is led via phloem to the apical meristems, determining the flowering central genes activation that will trigger differentiation of meristems (TAIZ and ZEIGER, 2013).

In strawberry, the interaction between temperature and photoperiod can control flowering in short day cultivars (COCCO et al., 2016). However, great part of short-day cultivars, like Camarosa, shows optional answer to flowering, that is, when the floral induction occurs continuously and regardless its photoperiod, once the temperatures are inferior to $15{ }^{\circ} \mathrm{C}$ (HEIDE et al., 2013; DURNER, 2015). In this study, the influence of the temperature in the inductive process upon the genotype was confirmed (lower $15^{\circ} \mathrm{C}$ ), predominating over the effect of the photoperiod.

The TSa necessary to begin the harvest was variable in the years (Figure 3). This attribute varied from 383 and $438^{\circ} \mathrm{C}$ days $^{-1}$ (2008 and 2009, respectively) to $816{ }^{\circ} \mathrm{C}$ days $^{-1}$ (2014). In plants whose interval between transplant and harvest is 73 days (2008 and 2009), the mean accumulation of degrees-days was $5.2^{\circ} \mathrm{C}_{\text {day }}{ }^{-1}(2008)$ and $6{ }^{\circ} \mathrm{C}_{\text {day }}{ }^{-1}$ (2009). But for plants whose interval is 111 days, the accumulation was $7.3^{\circ} \mathrm{C}_{\text {day }^{-1}}$ (2014).

The TSa was linked to temperature conditions that occurred in the period. In 2008, for instance, the mean temperature during the cycle was $14{ }^{\circ} \mathrm{C}$ and, in 2009 was $12{ }^{\circ} \mathrm{C}$, when less accumulation of cold hours is necessary to begin harvest in comparison with 2014, when the mean temperature recorded was $15{ }^{\circ} \mathrm{C}$. Even when 2008 and 2009 showed 73 days between transplant and harvest, the thermal need to reach the beginning of fruiting was different.

The temperatures recorded in the growth environment were directly related to the TSa by the plant, which is given as physiological time that is necessary to change the vegetative stage. The need for a greater TSa to reach the beginning of harvest represented an increase in the vegetative period, delaying the beginning of harvest. This fact determined the reduction of the fruiting period that can lead to a total lower yield of fruits (RAHMAN et al., 2016). This TSa was associated to the accumulation of cold hours that the cultivar received during the seedling formation. This fact determines the differentiation of flower bud. Besides these factors, which refer to temperatures, other factors in the natural environment, like photoperiod and solar radiation variation, influence this process (SØNSTEBY et al., 2016).

The cold accumulation is an important part of strawberry growth and production. The demand for cold in cultivars developed in California is comprised of two important parts. One part is what the plant accumulates in the field before digging, and the 
other one is the accumulation of cold after harvest, during storage (additional cold) in constant and close to freezing temperatures. The additional cold, under California conditions, is attributed to plants so that they easily withstand the stress caused by transplant (HIDAKA et al., 2017).

For years, strawberry genotypes developed and improved in California are provided to Chile as stock plants. After the multiplication of these stock plants, the seedlings are directed to the majority of the Brazilian subtropics producers. These seedlings show two categories: frigo and fresh. Frigo seedlings are characterized for receiving cold in the field and additional cold after harvest and they are generally neutral cultivars. The fresh ones accumulate cold in the greenhouse and, after being developed in the field are uprooted and then taken to producers, being then characterized as short-day cultivars.

Cultivar Camarosa, under its origin condition (California), needs until seven days of additional cold units accumulated after the accumulation in the field. Overall, the demand for cold of the cultivars developed in California is from 150 to 400 hours cold lower $7.2^{\circ} \mathrm{C}$ (STRAND, 2008). This information can be found in Lassen Canyon Nursery, located in California.

According to the models to estimate the cold units accumulated (BYRNE and BACON, 1992) under the Chilean Patagonia conditions, where the stock plants are multiplied, the temperature may not be enough to this accumulation of cold units, that is when we consider the seedlings to be fresh, which in the South Hemisphere do not receive additional cold. We emphasize that, in California, the winter period is longer and intense, turning the accumulation of cold units feasible. For strawberry, the cold hours accumulated must be from 28 to $45^{\circ}$ Fahrenheit (BOLDA, 2008) which correspond from -2.2 to $7.2^{\circ} \mathrm{C}$. It is emphasized that larger productions are obtained from seedlings that show higher crown diameter and higher carbohydrate content in reserve organs (COCCO et al., 2016).

It was observed that when the strawberry transplanted in May (from 2007 to 2010 respectively), in protected environment, in the Brazilian subtropic, the vegetative period is superior (from 5 to 7 months) when it was compared to other transplanting periods (Figure 1). Therefore, when the transplant of the seedlings is carried out in the first fortnight of July (2011 and 2012, respectively), there is a reduction in the vegetative stage of the plant, varying from 3 to 4 months. When the vegetative period is longer, there is a delay in the beginning of the reproductive cycle, which may be reduced. This is directly related to the seedlings quality, thus their crowns, whose diameter is more developed; determine greater accumulation of substances, causing precocity (non- published data).

Floral induction under the Brazilian subtropical conditions may be delayed by two main factors: 1) time reduced of the plants exposure to conditions which are necessary to the formation of seedlings with quality; 2) raised temperatures during the seedlings formation that are still in the nursery and, in the ambient, soon after transplant. These factors compromise the storage capacity of photoassimilates in the plants crown, which is determined by cold hours accumulated in the nursery.

When these seedlings arrive at their destination, soon after transplant, they may not show, satisfactorily, energetic substances in the crown that will determine the plant energy, configurating a period of continuity to this process. This will induce to the translocation of photoassimilates of this body to floral induction, causing damage to the processes associated with the carbon balance of the plant (SØNSTEBY et al., 2016).

Therefore, seedlings that arrive later in the Brazilian subtropic, like the ones that were transplanted in July, are more likely to bloom soon after transplant. This is due to the largest time of exposure to cold during the seedlings formation in the nursery. The greatest the accumulation of cold ( $\mathrm{o} h \mathrm{~h})$ during the seedling formation, the lowest the time which is necessary to begin flowering (HIDAKA et al., 2017).

It was also observed that, in 2007 and 2011, even when there were different vegetative periods (5 and 3 months, respectively), the seedlings that were transplanted in May showed the same fruiting time as those transplanted in July. Therefore, the late transplant is recommended, thus the seedlings will be less exposed to the negative influence of biotic and abiotic factors, since there is no reduction in their fruiting period. This way, it will be possible to reduce costs to the producer and contribute with the agroecosystem sustainability, minimizing the use of non-renewable resources.

We must take into consideration that, because of the delay in the seedlings delivery by the nursery or in the seedlings transplant, a productive gap is created, which may be filled with the implementation of short cycle horticultural crops, for subsequent implantation of strawberry in ambient, providing optimization in the space and greater profitability to the producer. 


\begin{tabular}{|c|c|c|c|c|c|c|c|c|c|c|c|c|c|c|c|c|c|c|}
\hline \multirow[b]{2}{*}{ Fortnights } & \multicolumn{2}{|c|}{ May } & \multicolumn{2}{|c|}{ Jun } & \multicolumn{2}{|c|}{ Jul } & \multicolumn{2}{|c|}{ Aug } & \multicolumn{2}{|c|}{ Sep } & \multicolumn{2}{|c|}{ Oct } & \multicolumn{2}{|c|}{ Nov } & \multicolumn{2}{|c|}{ Dec } & \multicolumn{2}{|l|}{ Jan } \\
\hline & $1^{a}$ & $2^{a}$ & $1^{\mathrm{a}}$ & $2^{a}$ & $1^{\mathrm{a}}$ & $2^{a}$ & $1^{\mathrm{a}}$ & $2^{a}$ & $1^{\mathrm{a}}$ & $2^{a}$ & $1^{a}$ & $2^{a}$ & $1^{\mathrm{a}}$ & $2^{a}$ & $1^{\mathrm{a}}$ & $2^{a}$ & $1^{\mathrm{a}}$ & $2^{a}$ \\
\hline 2007 & & & & & & & & & & & & & & & & & & \\
\hline 2008 & & & & & & & & & & & & & & & & & & \\
\hline 2009 & & & & & & & & & & & & & & & & & & \\
\hline 2010 & & & & & & & & & & & & & & & & & & \\
\hline 2011 & & & & & & & & & & & & & & & & & & \\
\hline 2012 & & & & & & & & & & & & & & & & & & \\
\hline 2013 & & & & & & & & & & & & & & & & & & \\
\hline 2014 & & & & & & & & & & & & & & & & & & \\
\hline
\end{tabular}

FIGURE 1- Crop cycles of cultivar Camarosa in protected environment.

Black: Transplant; dark gray: beginning of harvest; light gray : end of harvest.

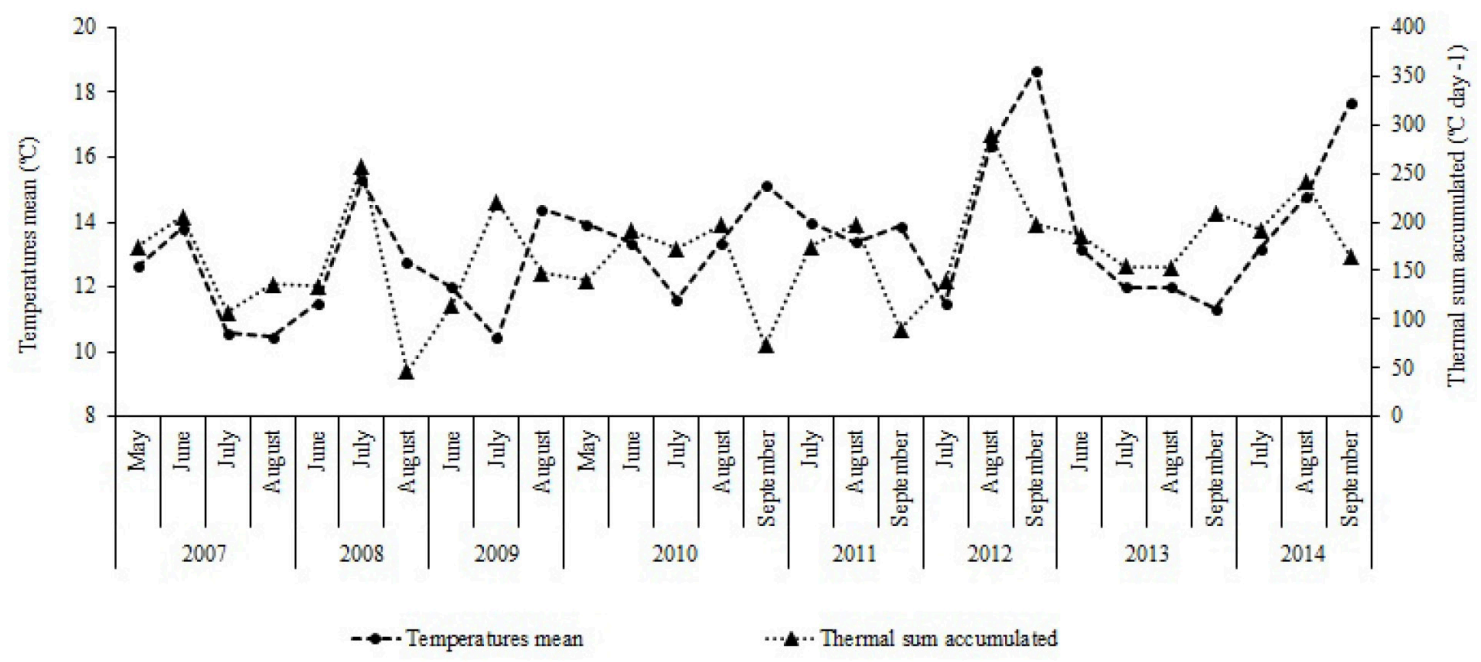

FIGURE 2- Mean temperatures $\left({ }^{\circ} \mathrm{C}\right)$ and thermal sum accumulated during seven years of study between transplant and beginning of harvest periods. 


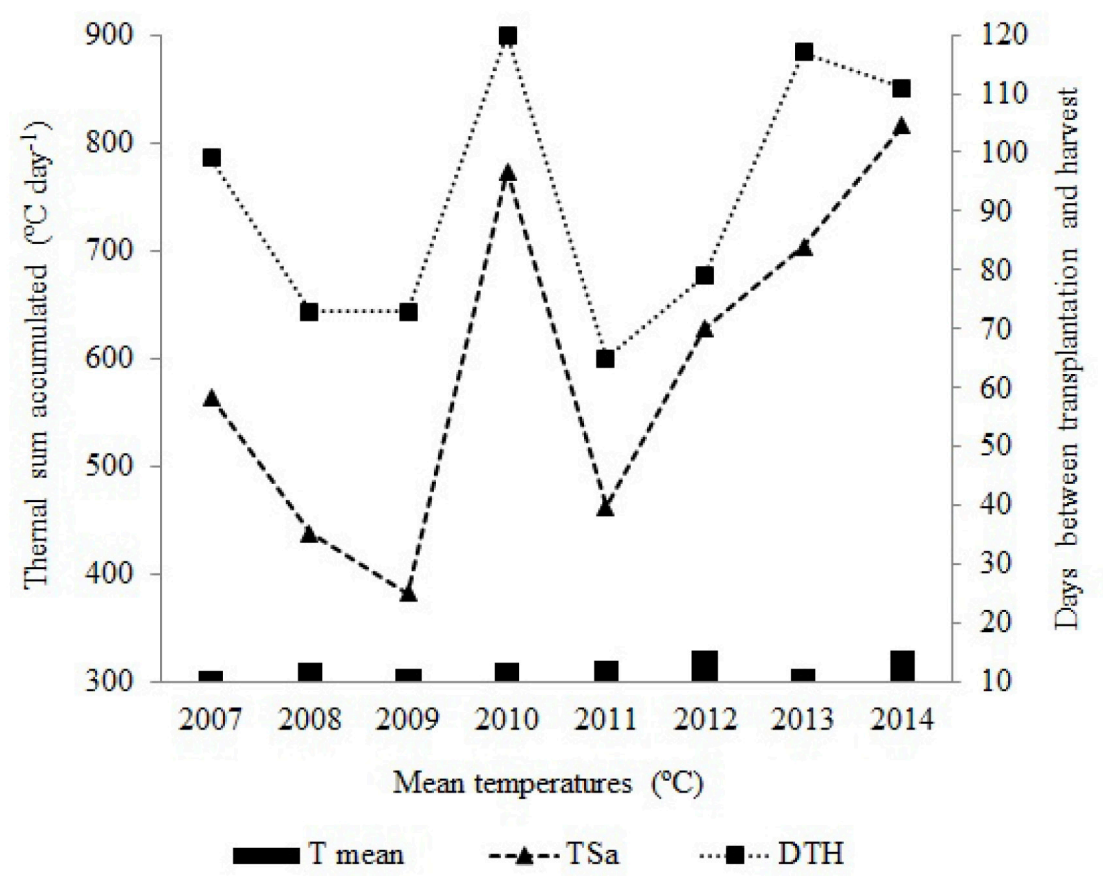

FIGURE 3- Mean temperatures $\left({ }^{\circ} \mathrm{C}\right)$, thermal sum accumulated (degrees-days) and days between transplant and beginning of harvest periods.

\section{CONCLUSION}

Depending on the temperatures recorded in different years of growth, there is alteration mainly in the vegetative stage of strawberry plants in protected environment. It is recommended that the transplant of strawberry seedlings of cultivar Camarosa in the Brazilian subtropic is carried out in the first fortnight of June and in the first fortnight of July, and the filling of the productive gap in the crop environment by short cycle horticultures.

\section{REFERENCES}

ARNOLD, C. Y. Maximum-minimum temperature as a basis for computing heat units. Proceedings American Society for Horticulture Science, Geneva, v.76, p.682-692, 1960.

BARTCZAK, M.; LISIECKA, J.; KNAFLEWSKI, M. Correlation between selected parameters of planting material and strawberry yield. Folia Horticulturae, Krakow, v. 22, n.1, p.9-12, 2010.

BOLDA, M. Chilling requirements in california strawberries. 2008. Disponível em: $<$ http://ucanr. edu/blogs/blogcore/postdetail.cfm?postnum $=722>$. Acesso em: 19 mai 2016.
BYRNE, D.H.; BACON, T.A. Chilling estimation: its importance and estimation. The Texas Horticultural, Texas, v.18, n.5, p.8-9, 1992.

CALVETE, E.O.; NIENOW, A.A.; WESP, C.L.; CESTONARO, L.; MARIANI, F.; FIOREZE, I.; CECCHETTI, D.; CASTILHOS, T. Produção hidropônica de morangueiro em sistema de colunas verticais, sob cultivo protegido. Revista Brasileira de Fruticultura, Jaboticabal, v.29, n.3, p.524-529, 2007.

COCCO, C.; FERREIRA, L. V.; GONÇALVES, M. A.; PiCOLOTTO, L.; ANTUNES, L. E. C. Strawberry yield submitted to different root pruning intensities of transplants. Revista Brasileira de Fruticultura, Jaboticabal, v.34, n.4, p.1284-1288, 2012.

COCCO, C.; GONÇALVES, M.A.; PICOLOTTO, L.; FERREIRA, L.V.; ANTUNES, L.E.C. Crescimento, desenvolvimento e produção de morangueiro a partir de mudas com diferentes volumes de torrão. Revista Brasileira de Fruticultura, Jaboticabal, v. 37, n. 4, p. $961-969,2015$.

COCCO, C.; GONÇALVES, M.A.; REISSER JUNIOR, C.; MARAFON, A.C.; ANTUNES, L.E.C. Carbohydrate content and development of strawberry 
transplants from Rio Grande do Sul and imported. Revista Brasileira de Fruticultura, Jaboticabal, v.38, n.4, e-581, 2016.

COCCO, K.L.T.; SCHMIDT, D.; CARON, B.O.; SOUZA, V.Q. de; FONTANA, D.C.; PAULA, G.M. de. Estimated phyllochron in low tunnel cultivated strawberry cultivars. Ciência Rural, Santa Maria, v.46, n.9, p.1546-1552, 2016.

COSTA, R.C.; CALVETE, E.O.; MENDONÇA, H.F.C.; CAMPAGNOLO, A.P.; CHIOMENTO, J.L.T. Performance of day-neutral strawberry cultivars in soilless culture. Australian Journal of Crop Science, Lismore, v.10, p.94-100, 2016.

COSTA, R.C.; CALVETE, E.O.; MENDONÇA, H.F.C.; DECOSTA, L.A. Phenology and leaf accumulation in vernalized and non-vernalized strawberry seedlings in neutral-days. Acta Scientiarum. Agronomy, Maringá, v.36, n.1, p.57-62, 2014.

DURNER, E.F. Photoperiod affects floral ontogeny in strawberry (Fragaria x ananassa Duch.) plug plants. Scientia Horticulturae, New York, v.194, p.154-159, 2015.

FU, Y.H.; CAMPIOLI, M.; DECKMYN, G.; JANSSENS, I. A. Sensitivity of leaf unfolding to experimental warming in three temperate tree species. Agricultural and Forest Meteorology, Amsterdam, v.181, p.125-132. 2013.

GE, Q.; WANG, H.; RUTISHAUSER, T.; DAI, J. Phenological response to climate change in China: A meta-analysis. Global Change Biology, Oxford, v.21, n.1, p.265-274, 2015.

GILMORE, E. C.; ROGERS, J. S. Heat units as a method of measuring maturity in corn. Agronomy Journal, Madison, n.10, v.50, p.611- 615, 1958.

HEIDE, O. M.; STAVANG, J. A.; SØNSTEBY, A. Physiology and genetics of flowering in cultivated and wild strawberries - a review. Journal of Horticultural Science and Biotechnology, Ashford, v.88, p.1-18, 2013.

HIDAKA, K.; DAN, K.; IMAMURA, H.; TAKAYAMA, T. Crown-cooling treatment induces earlier flower bud differentiation of strawberry under high air temperatures. Environmental Control in Biology, Fukuoka, v.55, n.1, p.21-27, 2017.
LOVAISA, N.C.; MOLINA, M.F.G.; QUINTANA, P.G.A.D.; SALAZAR, S.M. Response of strawberry plants inoculated with Azospirillum and Burkholderia at field conditions. Revista Agronómica del Noroeste Argentino, San Miguel de Tucumán, v.35, n.1, p.33-36, 2015.

RAHMAN, M.M.; SAHA, M.G.; ISLAM, M.N.; ULLAH, M.A.; QUAMRUZZAMAN, A.K.M. Phenology and yield of strawberry as influenced by planting time and genotypes in a sub tropical region. Pakistan Journal of Scientific and Industrial Research. Series B: Biological Sciences, Karachi, v. 59, n. 3, p. 126-132, 2016.

SØNSTEBY, A.; SOLHAUG, K.A.; HEIDE, O.M. Functional growth analysis of 'Sonata' strawberry plants grown under controlled temperature and daylength conditions. Scientia Horticulturae, New York, v.211, p.26-33, 2016.

STRAND, L. Integrated pest management for strawberries. $2^{\text {nd }}$ ed. Oakland: UCANR Publications, 2008. 176p.

TAIZ, L.; ZEIGER, E. Fisiologia vegetal. 5. ed. Porto Alegre: Artmed, 2013. 954p.

TAZZO, I.F.; FAGHERAZZI, A.F.; LERIN, S.; KRETZSCHMAR, A.A.; RUFATO, L. Exigência térmica de duas seleções e quatro cultivares de morangueiro cultivado no Planalto Catarinense. Revista Brasileira de Fruticultura, Jaboticabal, v.35, n.3, p.550-558, 2015.

TORRES-QUEZADA, E.A.; ZOTARELLI, L.; WHITAKER, V.M.; SANTOS, B.M.; HERNANDEZOCHOA, I. Initial crown diameter of strawberry bare-root transplants affects early and total fruit yield. HortTechnology, Alexandria, v.25, n.2, p.203-208, 2015.

WANG, H.; DAI, J.; ZHENG, J.; GE, Q. Temperature sensitivity of plant phenology in temperate and subtropical regions of China from 1850 to 2009. International Journal of Climatology, New York, v.35, p.913-922, 2015.

ZHANG, P.; ZHANG, J.; CHEN, M. Economic impacts of climate change on agriculture: the importance of additional climatic variables other than temperature and precipitation. Journal of Environmental Economics and Management, San Diego, v.83, p.8-31, 2017. 